\title{
The survival rate of virulent coagulase-negative staphylococci in pasteurized spiced kunu (a Nigerian non-alcoholic beverage)
}

\author{
*Fowoyo, P.T. \\ Microbiology Department, Baze University, Abuja, Nigeria
}

\begin{abstract}
Article history:
Received: 19 June 2019

Received in revised form: 10

July 2019

Accepted: 11 July 2019

Available Online: 19 July

2019
\end{abstract}

Keywords:

Кипи,

Coagulase-negative

Staphylococci,

Antimicrobial,

Fermented beverage,

Spices

DOI:

https://doi.org/10.26656/fr.2017.4(1).233

\begin{abstract}
Кипи is a non-alcoholic fermented beverage popularly consumed in Nigeria and attributed to possess immense nutritional and antimicrobial properties. The objective of this research was to determine the survival of virulent and antibiotic resistant coagulase-negative staphylococci (CoNS) in pasteurized spiced kunu. Kunu was prepared using the spices; clove and ginger and then pasteurized. The survival of five virulent and antibiotic resistant CoNS species; Staphylococcus simulans, Staphylococcus kloosi, Staphylococcus epidermidis, Staphylococcus caprae and Staphylococcus xylosus in pasteurized spiced kunu samples was determined at intervals of $0 \mathrm{hr}, 24 \mathrm{hrs}, 48 \mathrm{hrs}, 72 \mathrm{hrs}$ and $96 \mathrm{hrs}$. It was observed that there was a significant decrease of virulent and antibiotic resistant CoNS species in kunu samples prepared with high concentrations of the spice either alone or in combination. The virulent strains were below detectable limit from $48 \mathrm{hrs}$ especially for those prepared with a combination of spices at high concentration and that with clove alone. The un-spiced kunu (control) also inhibited the virulent species although the rate of decline was not as pronounced like the spiced kunu even at $96 \mathrm{hrs}$. This study had shown that kunu prepared with a combination of clove and ginger at high concentration of $30 \mathrm{mg}$ / $\mathrm{mL}$ exhibits antimicrobial activity against CoNS. Кипи may be used as an antimicrobial against gastrointestinal infections caused by these organisms. Further studies may be carried out using other gastrointestinal pathogens to fully explore and lend credence to the antimicrobial activity of spiced kunu.
\end{abstract}

\section{Introduction}

Food is a vital requirement for man; however, it also serves as a vehicle for transmission of pathogenic organisms to man. Food is rich with all the necessary nutrients therefore it is a rich medium that supports the growth of microbes. Recently, the isolation of pathogenic and antibiotic resistant microorganisms from food suggests that food could become a reservoir for the transmission of antibiotic resistance to man. Therefore, it is necessary for foods to be prepared, in such a way that they can act as antimicrobials themselves capable of limiting or killing pathogenic organisms present in food.

Microbial pathogens in food cause a variety of foodborne related diseases. Some common food-borne pathogens that have been reported to cause several diseases and also exhibit antibiotic resistance include Salmonella enterica serovar Typhimurium, Salmonella Salmonella enterica serovar Typhi, Vibrio cholerae, Shigella dysentariae, Campylobacter species, Staphylococcus aureus and more recently coagulasenegative staphylococci which is an emerging food-borne pathogen.

Coagulase-negative staphylococci were previously recognized as non-pathogenic organisms and commensals of the skin although, could become opportunistic. Recently, these organisms are not only associated as causes of nosocomial infections but have also been isolated in food.

It has been isolated from some Nigerian foods and discovered to exhibit virulent traits and antibiotic resistance (Fowoyo and Ogunbanwo, 2016a; Fowoyo and Ogunbanwo, 2016b; Fowoyo and Ogunbanwo, 2017). Coagulase negative staphylococci isolated from food samples exhibited the ability to produce biofilms, superantigenic enterotoxins, DNAse, TNAse, hyaluronidase, haemolysins and were resistant to broad spectrum antibiotics. Their ability to resist antibiotics was further demonstrated with genotypic analysis that indicated the presence of blaz and mecA genes in their genome. Their occurrence in food and especially their ability to produce enterotoxins similar to their coagulasepositive counterpart i.e. Staphylococcus aureus makes 
their incidence in food worrisome. It is estimated that over 200 types of diseases are caused or spread by food, sometimes causing long term health problems in vulnerable groups of people such as the elderly, pregnant women and infants (WHO, 2015). The majority of morbidity and mortality related to foodborne infections are caused by bacterial agents (CDC, 2011). Food-borne diseases remain a challenge globally, with a higher incidence rate in developing countries (BiranjiaHurdoyal and Latouche, 2016). The World Health Organization's Food-borne Disease Burden Epidemiology Reference Group estimated 582 million cases of food-borne diseases and 351,000 associated deaths worldwide (WHO, 2015). Food-borne pathogens are developing resistances to antibiotics which is an increasing health and economic problem worldwide. Many of these organisms are becoming resistant to routinely used antibiotics thereby making therapy ineffective. This continual concern about evolving antibiotic resistance and declining food safety especially in developing countries requires new strategies to be developed to combat this impending menace. The emerging antibiotic resistance in food-borne pathogens has paved the way for the use of natural antimicrobials such as spices in the food industry.

Kunu is a cereal food drink prepared using additives like spices and has become a popular refreshing nonalcoholic beverage in Nigeria. Кипu also protects the body against cholesterol and bile acid metabolism related diseases such as gallstones and certain forms of heart diseases (Olaitan et al., 2012). Kunu has been reported to elevate lymphocyte counts in the blood serum of albino rats fed with kunu which is indicative of its medicinal attributes, a concept widely believed by its numerous consumers (Akoma et al., 2006). Spices have long been added to enhance flavor and serve as preservatives in food however, more recently, attention has been drawn to the medicinal value of spices. It has also been reported that spices such as ginger and clove used in kunu preparation demonstrate antimicrobial activity against food pathogens (Lai and Roy, 2004; Joe et al., 2009, Sethi et al., 2013; Mane et al., 2014; Liu et al., 2017). The aim of this study is to determine the survival of CoNS in spiced pasteurized kunu samples.

\section{Materials and methods}

\subsection{Test organisms used for this study}

The virulent coagulase-negative staphylococci used were $S$. kloosii KIL 4, S. xylosus KIL 2, S. caprae NOMA 6, S. simulans NOJ 6, S. epidermidis IRIL 5. The organisms were identified from a previous study using phenotypic and genotypic methods. They were virulent and antibiotic resistant species of coagulase-negative staphylococci isolated from Nigerian fermented foods (Fowoyo and Ogunbanwo, 2016a, Fowoyo and Ogunbanwo, 2016b, Fowoyo and Ogunbanwo, 2017).

\subsection{Preparation of Spiced Kunu}

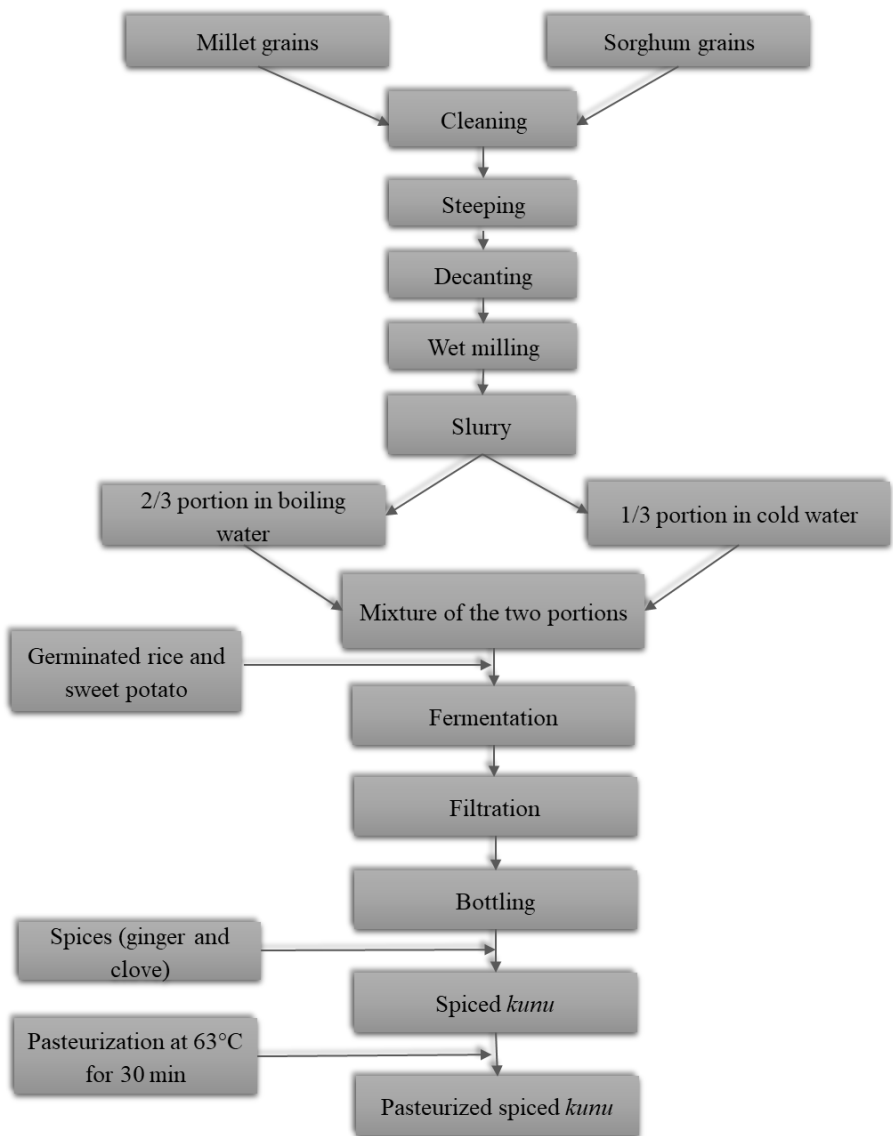

Figure 1. Flow chart for the preparation of spiced pasteurized kunu

Kunu was prepared according to the method described by Odunfa and Adeyele (1985) with slight modifications as shown in Figure 1. The raw materials for the preparation of kunu were purchased from the International Market, Lokoja, Nigeria. The raw materials were millet $(500 \mathrm{~g})$ and sorghum $(500 \mathrm{~g})$, spices (ginger and clove), sweet potato $(150 \mathrm{~g})$ and germinated rice $(100 \mathrm{~g})$. They were cleaned of extraneous materials and dirt by winnowing and washing. The millet and sorghum grains were mixed together and steeped in $15 \mathrm{~L}$ of sterile distilled water for $12 \mathrm{hrs}$. The grains were washed with sterile distilled water and wet milled hygienically to obtain a smooth, fine paste. The spices were dry milled separately not with the grains. The ground mixture of millet and sorghum were divided into 3 equal parts; $1 / 3$ was mixed with $5 \mathrm{~L}$ of sterile cold water and homogenized while $2 / 3$ was mixed with $8 \mathrm{~L}$ of boiling water to give a gel-like consistency. The $1 / 3$ part (cold suspension) was added to the gel-like part and mixed thoroughly. Sweet potatoes and germinated rice were cleaned and wet milled then, added to the mixture. This was covered with aluminum foil and fermented overnight at $30^{\circ} \mathrm{C}$ during which the slurry was allowed to 
settle and sediment. The slurry was sieved using a sterile and fine cloth. The resulting mixture was divided into ten portions. Kunu of $200 \mathrm{~mL}$ was dispensed into tight, sterile screw cap bottles to which the respective spices were added. A total of ten different kunu samples were prepared and labeled as KCG1: kunu spiced with $10 \mathrm{mg} /$ $\mathrm{mL}$ of each of clove and ginger, KCG2: kunu spiced with $20 \mathrm{mg} / \mathrm{mL}$ of each of clove and ginger, KCG3: kunu spiced with $30 \mathrm{mg} / \mathrm{mL}$ of each of clove and ginger, $\mathrm{KCl}$ : kunu spiced with $10 \mathrm{mg} / \mathrm{mL}$ of clove, $\mathrm{KC} 2$ : kunu spiced with $20 \mathrm{mg} / \mathrm{mL}$ of clove, KC3: kunu spiced with $30 \mathrm{mg} /$ $\mathrm{mL}$ of clove, KG1: kunu spiced with $10 \mathrm{mg} / \mathrm{mL}$ of ginger, KG2: kunu spiced with $20 \mathrm{mg} / \mathrm{mL}$ of ginger, KG3: kunu spiced with $30 \mathrm{mg} / \mathrm{mL}$ of ginger, C: Control (un-spiced kunu).

The kunu samples were pasteurized using low temperature holding method in a hot water bath at a temperature of $63^{\circ} \mathrm{C}$ for 30 mins. The survival of virulent CoNS was determined in the spiced, pasteurized kunu samples to elucidate the efficacy and antimicrobial potential of spiced kunu against these pathogens that are antibiotic resistant that occur in food.

\subsection{Survival of virulent coagulase - negative} staphylococci in laboratory prepared pasteurized spiced kunu

The modification of the method by Simango and Rukure (1992) was used to determine the survival of virulent CoNS in laboratory prepared pasteurized and spiced kunu. The sterility of each spiced kunu sample was checked by performing total plate count. The virulent CoNS species were each inoculated into brain heart infusion broth and incubated at $37^{\circ} \mathrm{C}$ for $18 \mathrm{hrs}$. The 18-hour-old broths were standardized and the turbidity adjusted to correspond to 0.5 MacFarland standard, and this was used as the inoculum. The standardized inoculum $(1 \mathrm{~mL})$ was plated out on nutrient agar plates using the spread plate technique and this directly correlates to the initial microbial count in $1 \mathrm{~mL}$ of each spiced, pasteurized kunu sample. The cell suspension or inoculum $(1 \mathrm{~mL})$ was dispensed into 50 $\mathrm{mL}$ of the sterile spiced kunu sample in $100-\mathrm{mL}$ bottles and the content was thoroughly mixed. The inoculated samples were kept at $25^{\circ} \mathrm{C}$. Surviving bacterial cells were enumerated by plating out at different time intervals of $0 \mathrm{~h}, 24 \mathrm{hrs}, 48 \mathrm{hrs}, 72 \mathrm{hrs}$ and $96 \mathrm{hrs}$ on duplicate Baird Parker agar. The agar plates were incubated at $37^{\circ} \mathrm{C}$ for $24 \mathrm{hrs}$. Colonies morphologically representative of each pathogenic CoNS were counted on the plates using a colony counter and the values were multiplied by the corresponding dilution factor to get the total bacterial count.

\section{Results}

The kunu samples that were spiced with clove alone at high concentration and that spiced with a combination of ginger and clove had the highest inhibitory effect on the strains.

At $48 \mathrm{hrs}$, there was a steady decline in microbial count from $5.49 \log _{10} \mathrm{CFU} / \mathrm{mL}-0 \log _{10} \mathrm{CFU} / \mathrm{mL}$ for all the virulent species in the kunu (KCG3 and KC3) samples. The microbial count of $S$. kloosii and $S$. simulans also decreased to $0 \log _{10} \mathrm{CFU} / \mathrm{mL}$ at $48 \mathrm{hrs}$ in KCG2 and KC3 samples. It was also observed that the kunu samples prepared with higher concentrations of the spice either alone or in combination rapidly reduced the microbial count of the virulent CoNS in the spiced kunu samples.

The inhibitory effect of $\mathrm{KCG} 2, \mathrm{KC} 2, \mathrm{KG} 3$ and $\mathrm{KC} 1$ kunu samples against the virulent species was very high at $72 \mathrm{hrs}$ and were no longer detectable. It was observed that KCGI, KG2 and KG1 decreased the microbial count of $S$. simulans while KC3 decreased the microbial count for $S$. kloosii to $0 \log _{10} \mathrm{CFU} / \mathrm{mL}$ at $72 \mathrm{hrs}$. At $96 \mathrm{hrs}$, KG2 and KG1 inhibited $S$. xylosus and $S$. caprae while KCG1, KC2 and KG1 inhibited S. epidermidis although, KCG1, KC2 and KG1 inhibited S. kloosii.

S. simulans was the most inhibited because at $72 \mathrm{hrs}$, the microbial count had dropped to $0 \log _{10} \mathrm{CFU} / \mathrm{mL}$ in all the kunu samples irrespective of the concentration or combinative effect of spices. $S$. simulans was not detected between 48 and $72 \mathrm{hrs}$ showing that the organisms were greatly inhibited in the spiced kunu samples irrespective of the concentration used. At $24 \mathrm{hrs}$, S. xylosus was nearly undetectable in the kunu samples and this demonstrates the antagonistic effect of the spiced kunu on the microorganisms. S. kloosii, S. caprae and $S$. epidermidis showed more resistance as compared to the other species, that were not detectable at $48 \mathrm{hrs}, 72$ hrs and 96 hrs. They were inhibited at $48 \mathrm{hrs}$ in the kunu sample prepared with a combination of the spices at higher concentrations

The potency of KCG3, KC3, KCG2 and KG3 was the highest decreasing the microbial counts to $0 \log _{10}$ $\mathrm{CFU} / \mathrm{mL}$ at $48 \mathrm{hrs}$ for all the virulent strains excluding KG3 that had its profound effect only on S. simulans. The kunu samples that were spiced with clove alone and that spiced with a combination of ginger and clove had the highest inhibitory effect on the strains. There was a steady decline in microbial count from $5.49 \log _{10} \mathrm{CFU} /$ $\mathrm{mL}-0 \log _{10} \mathrm{CFU} / \mathrm{mL}$ at $48 \mathrm{hrs}$ for all the CoNS species in kunu samples prepared using only one spice or a combination of spice at higher concentrations.

The virulent strains were below detectable limit from 


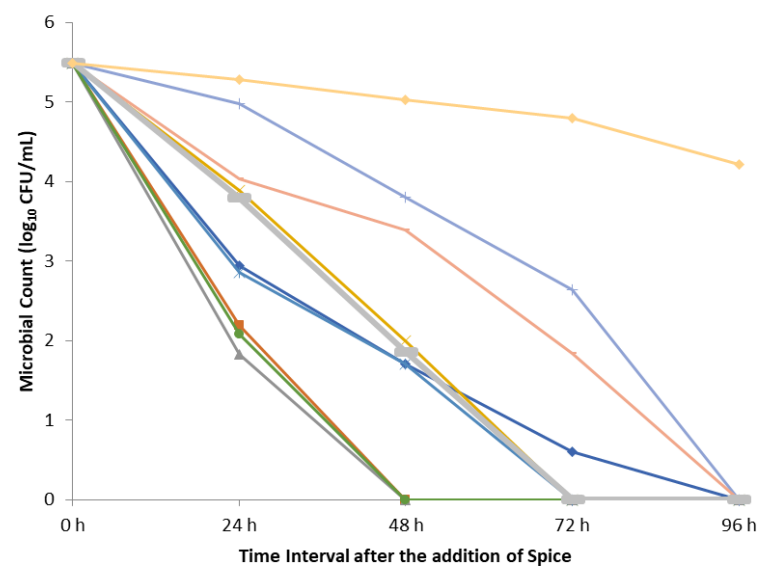

Figure 2. Survival pattern of $S$. kloosii KIL 4 in pasteurized Kunu at different spice concentration
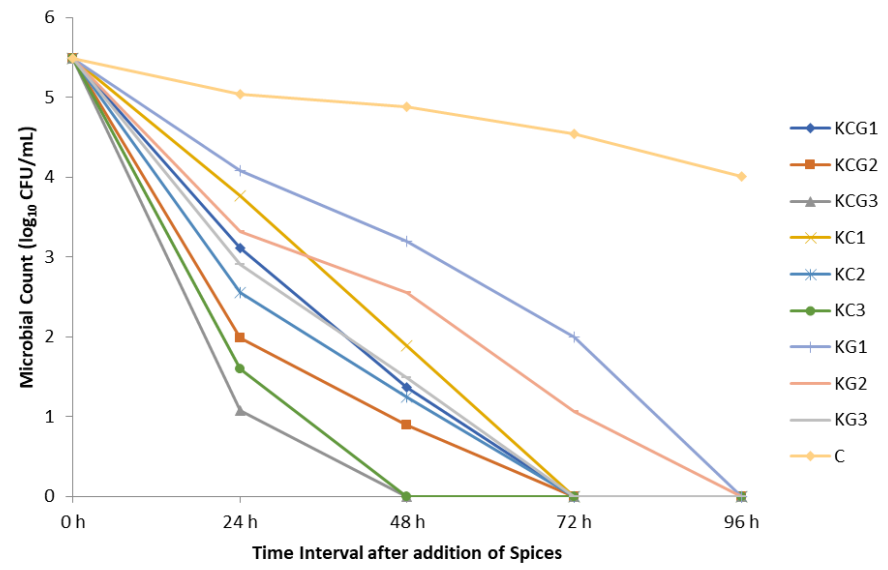

Figure 4. Survival pattern of $S$. caprae NOMA 6 in pasteurized Kunu at different spice concentration

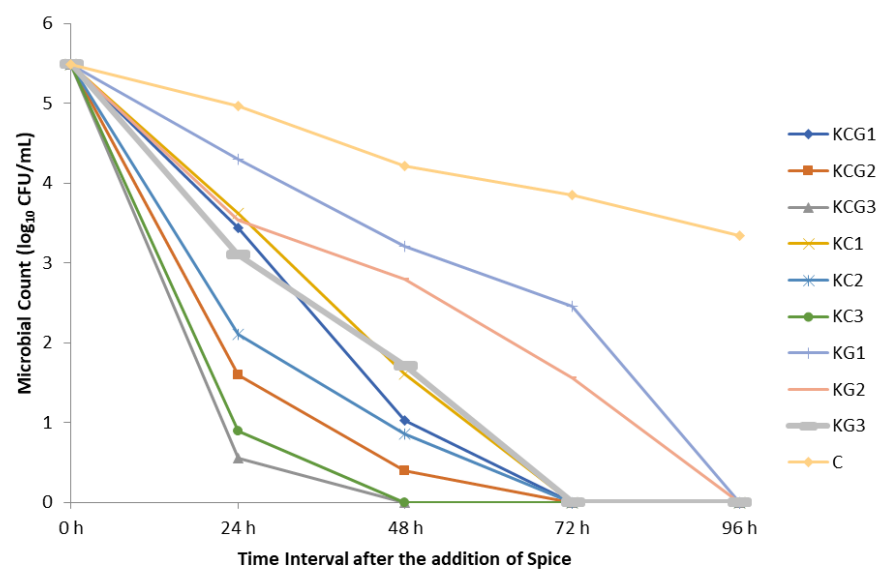

Figure 3. Survival pattern of S. xylosus KIL 2 in pasteurized Kunu at different spice concentration

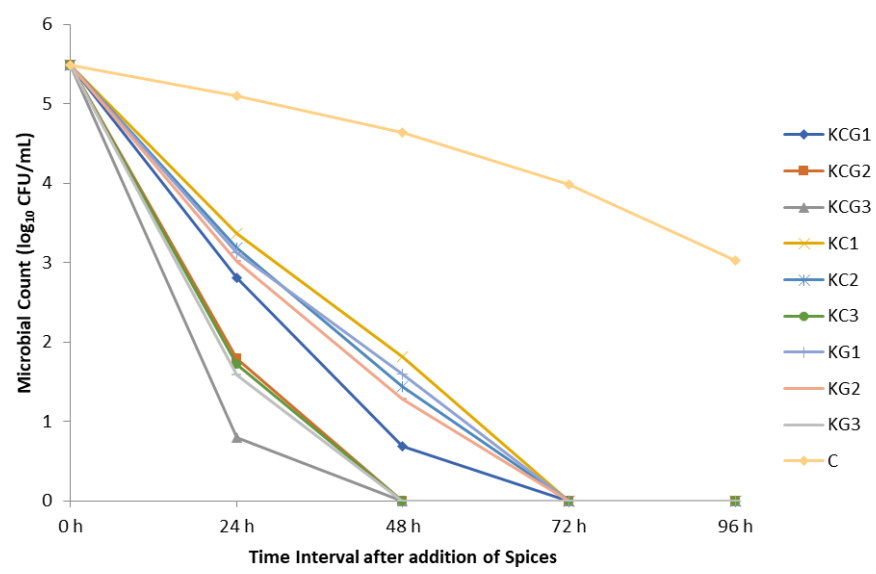

Figure 5. Survival pattern of $S$. simulans NOJ 6 in pasteurized Kunu at different spice concentration

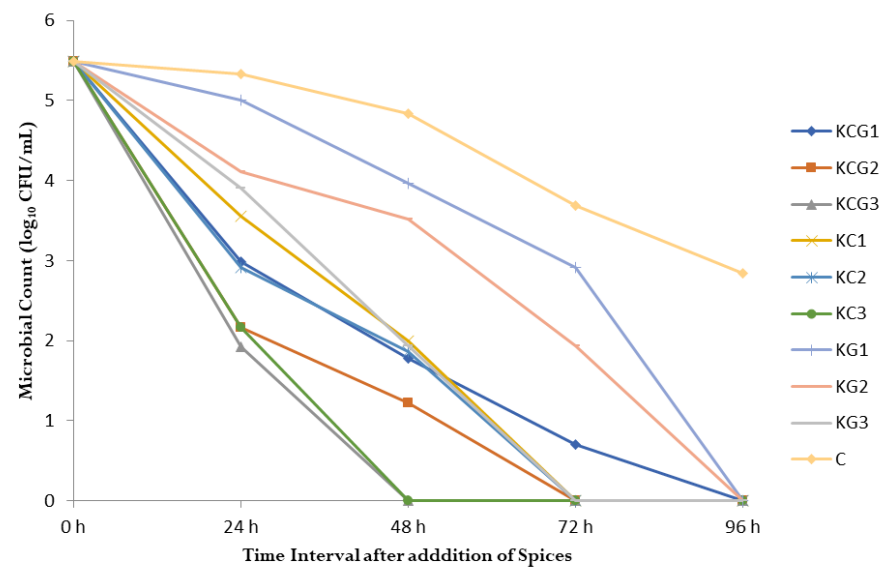

Figure 6. Survival pattern of $S$. epidermidis IRIL 5 in pasteurized Kunu at different spice concentration

KCG1, KCG2, KCG3: Kunu prepared with clove and ginger at concentrations of $10 \mathrm{mg}, 20 \mathrm{mg}$ and $30 \mathrm{mg}$ respectively; KC1, KC2, KC3: Кипи prepared with only clove at concentrations of $10 \mathrm{mg}, 20 \mathrm{mg}$ and $30 \mathrm{mg}$ respectively; KG1, KG2, KG3: Кипu prepared with only ginger at concentrations of $10 \mathrm{mg}, 20 \mathrm{mg}$ and $30 \mathrm{mg}$ respectively; C: control without spice.

$48 \mathrm{~h}$ especially for those prepared with combined spices at higher concentration and that with clove alone. The un -spiced kunu (control) also inhibited the virulent species though the rate of decline was not as pronounced like the spiced kunu even at 96 hrs. (Figures 2 - 6).

\section{Discussion}

The test organisms were below detectable limit in the pasteurized spiced kunu samples between 48 and 72 hrs especially for those prepared with high concentration of clove alone and, a combination of ginger and clove within a short time. The kunu samples; KCG3 and KC3 demonstrated high antimicrobial activity against $S$. kloosi, S. simulans, S. epidermidis, S. caprae and $S$. xylosus within $48 \mathrm{hrs}$ and this may be attributed to the high amounts of the phytochemicals thus within a short 
time they can elucidate their effect and lower the microbial count. Thus, a combination of the spices and the quantity of the spices used in preparing the kunu has a significant effect on the strains. A similar study carried out by Kong et al. (2007) on the combinatory effect of spices on vacuum packaged chilled pork also confirms that the presence of multiple active compounds in mixed spices could illicit stronger antimicrobial effects as compared to when the spices were used alone and this explains their synergistic bacteriostatic actions. This phenomenon apparently contributes to the antimicrobial potential of the drink to lower microbial count. Also, the high quantity of clove and ginger used in kunu preparation may have also contributed significantly to the decline in microbial count.

Clove has been reported to be used in treating infectious diseases and to protect food because they have been experimentally proven to possess antimicrobial activities against pathogenic and spoilage bacteria and fungi (Liu et al., 2017). Clove is also commonly applied in the food industry as a natural additive to increase shelf -life and also act as an antimicrobial against food-borne pathogens (Liu et al., 2017). A study carried out by (Liu et al., 2012) demonstrates the antimicrobial potential of clove in food in which the extract and essential oil of clove had the highest inhibitory effect against the microbial populations in chilled pork. Ginger also used in kunu preparation contributed to the inhibitory activity exhibited by the kunu samples. Ginger owes its antibacterial activity to its main component sesquiterpenoids (Gull et al., 2012). The antimicrobial activity of ginger against several pathogenic organisms was also demonstrated in a study by Goswami et al. (2014) against Clostridium perfringes, Escherichia coli and Clostridium sporogenes in minced chicken meat. The ginger was incorporated into the minced chicken meat by kneading and the pathogenic organisms were then inoculated into the meat samples. The microbial count was lowered considerably in the meat samples. The antimicrobial activity of the kunu samples was enhanced due to the antimicrobial activity derived from the spices (Olaitan et al., 2012).

S. simulans was the most inhibited of all the test organisms. It was inhibited greatly in four different kunu samples which was noticeable at $24 \mathrm{hrs}$ and this indicates the susceptibility of $S$. simulans to the spiced kunu samples. All the strains were slightly inhibited in unspiced kunu and this may be explained using the study carried out by Olaitan et al. (2012) which reported that $k u n u$ is self-sanitizing and had antimicrobial potential because of the presence of phenol and polyphenols present in the millet and sorghum grain used for its preparation.

\section{Conclusion}

The combination and quantity of spices, the phytochemical -phenol and polyphenols present in the raw materials used in preparing kunu plays an apparent role in inhibiting virulent CoNS. Foods prepared with spices possessing antimicrobial property could represent a likely alternative to antibiotics against food-borne pathogens. Combinatory or synergistic effect and use of high quantity of spices in food preparation may be a likely method of inhibiting food- borne pathogens.

\section{Conflict of Interest}

Author declares no conflict of interest.

\section{Acknowledgments}

Prof. S.T. Ogunbanwo of the Microbiology Department, University of Ibadan, Nigeria contributed immensely to this study by critiquing this work.

\section{References}

Biranjia-Hurdoyal, S. and Latouche, M.C. (2016). Factors affecting microbial load and profile of potential pathogens and food spoilage bacteria from household kitchen tables. Canadian Journal of infectious Diseases and Medical Microbiology, 2016, 1-6. https://doi.org/10.1155/2016/3574149

CDC (Centers for Disease Control and Prevention). (2011). Estimates of foodborne Illness in the United States. Retrieved from CDC website: http:// www.cdc.gov/foodborneburden/index.html.

Fowoyo, P.T. and Ogunbanwo, S.T. (2016a). Occurrence and characterization of coagulase-negative staphylococci from Nigerian traditional fermented foods. Food Science and Quality Management, 50, 49-55.

Fowoyo, P.T. and Ogunbanwo, S.T. (2016b). Virulence and toxigenicity of coagulase-negative staphylococci in Nigerian traditional fermented foods. Canadian Journal of Microbiology, 62(7), 572 - 578. https:// doi.org/10.1139/cjm-2015-0752

Fowoyo, P.T. and Ogunbanwo, S.T. (2017). Antimicrobial resistance in coagulase-negative staphylococci from Nigerian traditional fermented foods. Annals of Clinical Microbiology and Antimicrobials, 16, 4. https://doi.org/10.1186/s12941 $-017-0181-5$

Goswami, M., Prabhakaran, P.P. and Tanwar, V.K. (2014). Antioxidant and antimicrobial effects of condiments paste used as nitrite replacer in chicken mince. Veterinary World, 7(6), 432-438. https:// 
doi.org/10.14202/vetworld.2014.432-438

Joe, M.M., Jayachitra, J. and Vijayapriya, M. (2009). Antimicrobial activity of some common spices against certain human pathogens. Journal of Medicinal Plants Research, 3(11), 1134 - 1136.

Kong, B., Wang, J. and Xiong, Y.L. (2007). Antimicrobial activity of several herb and spice extracts in culture medium and in vacuum-packaged pork. Journal of Food Protection, 70(3), 641 - 647. https://doi.org/10.4315/0362-028X-70.3.641

Lai, P.K. and Roy, J. (2004). Antimicrobial and chemopreventive properties of herbs and spices. Current Medicinal Chemistry, 11(11), 1451 - 1460. https:// doi.org/10.2174/0929867043365107

Liu, G.-Q., Zhang, L.-L., Zong, K., Wang, A.-M. and $\mathrm{Yu}, \mathrm{X} .-\mathrm{F}$. (2012). Effects of spices essential oils on the spoilage-related microbiota in chilled pork stored in antimicrobial pack. Food Science and Technology Research, 18(5), 695-704. https://doi.org/10.3136/ fstr. 18.695

Liu, Q., Meng, X., Li, Y., Zhan, C.-N., Tang, G.-Y. and Li, H.-B. (2017). Antibacterial and Antifungal Activities of spices. International Journal of Molecular Sciences, 18(6), 1-6. https:// doi.org/10.3390/ijms18061283

Mane, B.G., Khurana, S.K., Choudhary, S. and Dhanze, H. (2014). Effect of natural Antimicrobials on Foodborne pathogens and Shelf life: A Review. Bioscience, Bioengineering and Biotechnology, 1, 22 -31 .

Odunfa, S.A. and Adeyele, S. (1985). Microbiological changes during the traditional production of 'ogi baba'. West African fermented sorghum gruel. Journal of Cereal Science, 3(2), 173-180. https:// doi.org/10.1016/S0733-5210(85)80027-8

Olaitan, J.O., Adeleke, O.E. and Alabi, O.S. (2012). Effect of kunnu-zaki on clinical bacteria isolates. African Journal of Biotechnology, 11(20), 46464648. doi: 10.5897/AJB11.3229.

Sethi, S., Dutta, A., Gupta, B. and Gupta, S. (2013). Antimicrobial activity of spices against isolated food -borne pathogens. International Journal of Pharmacy and Pharmaceutical Sciences, 5(1), 260 262.

Simango, C. and Rukure, G. (1992). Survival of bacterial enteric pathogens in traditional fermented foods. Journal of Applied Bacteriology, 73(1), 37-40. https://doi.org/10.1111/j.1365-2672.1992.tb04966.x

WHO (World Health Organization). (2015). 10 Facts on Food Safety. Retrieved on 14 November 2018 from WHO website: http://www.who.int/features/factfiles/ food_safety/facts/en/index.html. 